\title{
PENTINGNYA MENJAGA IMUNITAS BAGI LANSIA DI MASA PANDEMI COVID 19
}

https://doi.org/10.33024/jkpm.v4i6.4576

\author{
Ganik Sakitri ${ }^{*}$, Ratna Kusuma Astuti² \\ 1-2Politeknik Insan Husada Surakarta
}

Disubmit: 24 Juni 2021 Diterima: 10 Oktober 2021 Diterbitkan: 01 Desember 2021

Email Korepondensi: ganiksakitri2312@gmail.com

\begin{abstract}
ABSTRAK
Covid-19 adalah virus baru penyebab penyakit saluran pernafasan. Untuk mendukung program pemerintah dalam upaya memutus rantai penularan Covid19 perlu partisipasi dan dukungan dari masyarakat. Menjaga imunitas sangat penting terutama ditengah pandemi Covid-19. Tujuan dari kegiatan pengabdian masyarakat ini adalah memberikan pendidikan kesehatan kepada masyarakat dalam pencegahan covid 19. Upaya promosi kesehatan ini dapat dilakukan dengan menggunakan berbagai metode dan media yang dapat disesuaikan dengan sasaran. Cara efektif dalam pendekatan kelopok adalah dengan metode ceramah dan alat bantu yaitu leaflet. Terdapat peningkatan pengetahuan lansia tentang covid 19 di desa Kedungan, Pedan, Klaten.
\end{abstract}

Kata kunci: Lansia, imunitas, covid 19

\section{ABSTRACT}

Covid-19 is a new virus that causes respiratory disease. To support government programs in an effort to break the chain of transmission of Covid-19 needs the participation and support of the community. Maintaining immunity is very important, especially in the midst of the Covid-19 pandemic. The purpose of this community service activity is to provide health education to the community in preventing COVID-19. This health promotion effort can be done using various methods and media that can be adapted to the target. The effective way in the group approach is the lecture method and assistive tools, namely leaflets. There is an increase in the knowledge of the elderly about covid 19 in the village of Kedungan, Pedan, Klaten.

Keywords: Elderly, immunity, covid 19

\section{PENDAHULUAN}

Covid-19 adalah virus baru penyebab penyakit saluran pernafasan (WHO, 2020). Virus ini berasal dari provinsi Hubai, China. Covid-19 merupakan satu keluarga dengan virus penyebab Severe Acute Respiratory Syndrome (SARS) dan Middle East Respiratory Syndrome (MERS). Covid-19 Disease 2019 (Covid-19) adalah penyakit jenis baru yang belum pernah diidentifikasi sebelumnya pada manusia.virus penyebab Covid-19 ini dinamakan Sars-Cov-2 (Kemenkes RI, 2020). Berdasarkan bukti ilmiah, 
COVID-19 dapat menular dari manusia ke manusia melalui percikan batuk/bersin (droplet), tidak melalui udara. Untuk memutus mata rantai penularan Covid-19 pemerintah mengeluarkan kebijakan yang mengharuskan seluruh masyarakat untuk diam di rumah (Stay at Home), bekerja dari rumah (Work From Home), Belajar dari rumah, Social Distancing atau Physical Distancing (jaga jarak minimal 1,5 meter), Pembatasan Sosial Berskala Besar (PSBB) serta Pembatasan Sosial Berskala Kecil (PSBK). Selain itu 5 hal penting untuk mencegah Covid-19 yaitu dengan melakukan Cuci Tangan Pakai Sabun (CTPS), bekerja, belajar, beribadah dirumah, jaga jarak dan hindari kerumunan, tidak berjabat tangan dan gunakan masker bila sakit atau keluar dari rumah dan berada di tempat umum (Isfandiari, 2020).

Untuk mendukung program pemerintah dalam upaya memutus rantai penularan Covid-19 perlu partisipasi dan dukungan dari masyarakat agar tetap stay at home (diam dirumah) dengan cara menjaga kesehatan agar tetap sehat dan produktif yaitu dengan menjaga imunitas atau daya tubuh agar terhindar dari penularan Covid-19. Menjaga imunitas atau daya tahan tubuh merupakan salah satu cara gar dapat terhindar dari infeksi virus termasuk Covid-19.

Menjaga imunitas sangat penting terutama ditengah pandemi Covid19. Meskipun tubuh memiliki imunitas yang dapat dihasilkan sendiri yang merupakan imunitas alamiah yang berperan sebagai sistem pertahanan tubuh dalam melawan benda asing yang masuk ke dalam tubuh namun tubuh juga memerlukan imunitas dari luar yang dapat membantunya dalam menjaga sistem kekebalan tubuh. Cara agar dapat meningkatkan sistem imunitas tubuh selama masa pandemi Covid-19 adalah mengkonsumsi gizi seimbang yaitu mengkonsumsi makanan yang mengandung zat gizi atau nutrisi yang diperlukan oleh tubuh dan sesuai dengan kebutuhan tubuh yaitu mengkonsumsi makanan yang beranekaragam yang mengandung karbohidrat, protein, vitamin dan mineral dan perbanyak mengkonsumsi sayur dan buah, konsumsi makanan yang mengadung vitamin $A, C, E$ dan $D$ yang terdapat pada sayur dan buah yang dapat memperbaiki daya tahan tubuh.

Angka kematian lansia di Idonesia akibat virus covid-19 menurut Prof. Wiku pada usia 46 sampai 59 tahun, jumlah kematian akibat COVID-19 mencapai $6,11 \%$. Sementara kematian yang usianya di atas 60 tahun totalnya $14,67 \%$ atau mencapai 6.447 orang. Adapun angkanya $5.44 \%$ dengan jumlah pasien 5.678 orang yang meninggal. Di Jawa Tengah sendiri kasus covid-19 ini cukup tinggi yaitu pada usia 50-69 tahun dengan jumlah laki-laki 755 orang dan perempuan 533 orang.

Sedangkan di Klaten jumlah kumulatif pasien terkonfirmasi Covid-19 di Klaten mencapai 590 orang. Sebanyak 116 orang menjalani perawatan di RS/menjalani isolasi mandiri. Sebanyak 453 orang dinyatakan sembuh. Sebanyak 21 orang meninggal dunia. Dan di kecamatan pedan terkonfirmasi ada 62 orang. Serta di Desa Kedungan terdapat 2 orang terkonfirmasi (Dinkes klaten, 2021).

Perubahan pengetahuan covid-19 pada lansia merupakan suatu perubahan tingkat pengetahuan ke arah yang lebih baik dari sebelumnya. Perubahan pengetahuan ini diharapkan dapat memperbaiki perubahan sikap dan perilaku lansia. Upaya promosi kesehatan ini dapat dilakukan dengan menggunakan berbagai metode dan media yang dapat disesuaikan dengan sasaran. Cara efektif dalam pendekatan kelopok adalah dengan metode ceramah dan alat bantu yaitu leaflet. Pada metode ceramah dapat terjadi perubahan perilaku dan sikap. Sedangkan leaflet merupakan sarana publikasi 
singkat yang berbentuk selembar kertas dan berukuran kecil. Biasanya berisikan informasi yang perlu disebarkan pada masyarakat luas.

Walaupun telah banyak dilakukan penyuluhan tentang covid-19, namun masih banyak lansia yang belum sepenuhnya paham. Oleh karena itu, penulis berusaha memperbaiki dan menambahkan pengetahuan kepada lansia tentang covid-19 ini.

\section{MASALAH}

Pemilihan tempat kegiatan di dukuh Jalinan RT 02 RW 02 Kedungan, Pedan, Klaten. Lansia di dukuh Jalinan sebanyak 30 orang, sedangkan peserta yang diundang adalah 12 orang karena pembatasan publik. Alasan pemilihan lokasi tersebut selain Karena jumlah lansia banyak juga didapatan data bahwa lansia di dukuh tersebut kurang benar dalam pemakaian masker dan kurang mengetahui tentang pencegahan covid 19.

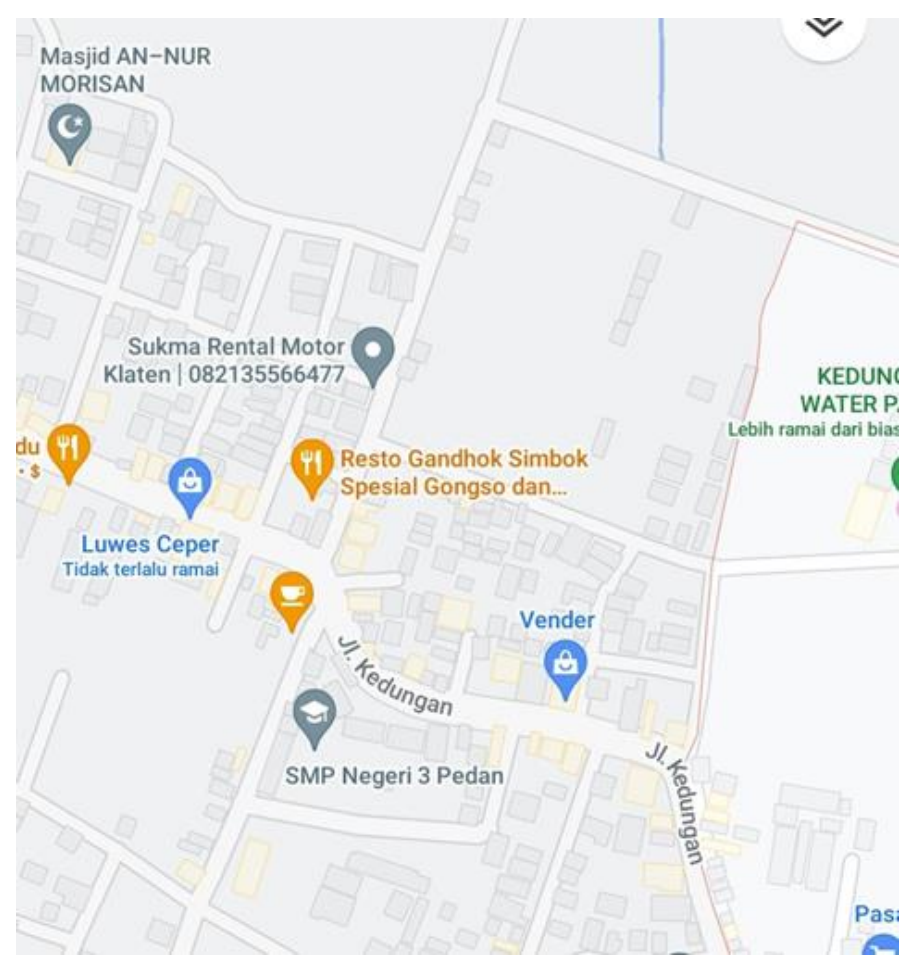

Gambar Peta lokasi kegiatan

\section{METODE}

a. Tahap persiapan

Tahap persiapan dari kegiatan adalah pembuatan preplanning dan perijinan kepada RT untuk pelaksanaan pendidikan kesehatan di desa Kedungan. Kemudian mempersiapkan media pelaksanaan pendidikan kesehatan. Media yang dipergunakan adalah leaflet dan power point.

b. Tahap pelaksanaan

Pelaksanaan pendidikan kesehatan tentang upaya pencegahan dan pengendalian covid-19 pada hari Rabu 3 Februari 2021. Pendidikan kesehatan dilakukan di rumah bapak RT. Pelaksanaan pendidikan kesehatan dengan protocol kesehatan dimulai dari cuci tangan, pengukuran suhu tubuh, memakai masker dan menjaga jarak. 
c. Evaluasi

1) Struktur

Pendidikan kesehatan tentang upaya pencegahan dan pengendalian covid 19 dihadiri 12 orang. Acara juga dihadiri oleh petugas kesehatan dari puskesmas kedungan.

2) Proses

Proses penyampaian materi berlangsung sangat baik dan peserta mematuhi protocol kesehatan yang diterapkan.

\section{HASIL DAN PEMBAHASAN}

a. Hasil

Pelaksanaan pendidikan kesehatan yang dilakukan di desa Jalinan RT 02 RW 02 Kedungan Pedan telah diikuti 12 peserta lansia. Adapun karakteristik dari peserta sebagai berikut:

1) Karakteristik responden berdasarkan usia

Tabel 1. Karakteristik responden berdasar usia menurut

\begin{tabular}{ccc}
\hline Usia & Frekueni & Presentasi (\%) \\
\hline 55-65 tahun & 8 & 66 \\
$>$ 65 tahun & 4 & 34 \\
Jumlah & 12 & 100 \\
WHO, 2016 & &
\end{tabular}

Berdasarkan karakteristik bahwa responden terbanyak adalah usia 55 - 65 tahun sebanyak $66 \%$, dan responden usia > 65 tahun sebanyak $34 \%$ responden.

2) Karakteristik responden berdasarkan

Tabel 1. Karakteristik responden berdasarkan jenis kelamin

\begin{tabular}{lcc}
\hline Jenis kelamin & Frekuensi & $\begin{array}{c}\text { Presentase } \\
\text { (\%) }\end{array}$ \\
\hline Laki-laki & 5 & 41,6 \\
Perempuan & 7 & 58,3 \\
Jumlah & 2 & 100 \\
\hline
\end{tabular}

Berdasarkan karakteristik jenis kelamin bahwa responden terbanyak adalah perempuan sebanyak $58,3 \%$, dan responden laki-laki sebanyak $41,6 \%$ responden.

3) Karakteristik responden berdasarkan tingkat pendidikan

Tabel 3. Karakteristik responden berdasarkan tingkat pendidikan

\begin{tabular}{ccc}
\hline $\begin{array}{c}\text { Tingkat } \\
\text { Pendidikan }\end{array}$ & Frekuensi & $\begin{array}{c}\text { Presentase } \\
(\%)\end{array}$ \\
\hline Rendah & 2 & 16,6 \\
Menengah & 6 & 50 \\
Tinggi & 4 & 33,4 \\
Jumlah & 12 & 100 \\
\hline
\end{tabular}


Berdasarkan karakteristik responden berdasarkan tingkat pendidikan terbanyak adalah tingkat pendidikan menengah sebanyak $50 \%$ dan tingkat pendidikan rendah sebanyak $16,6 \%$.

\section{b. Pembahasan}
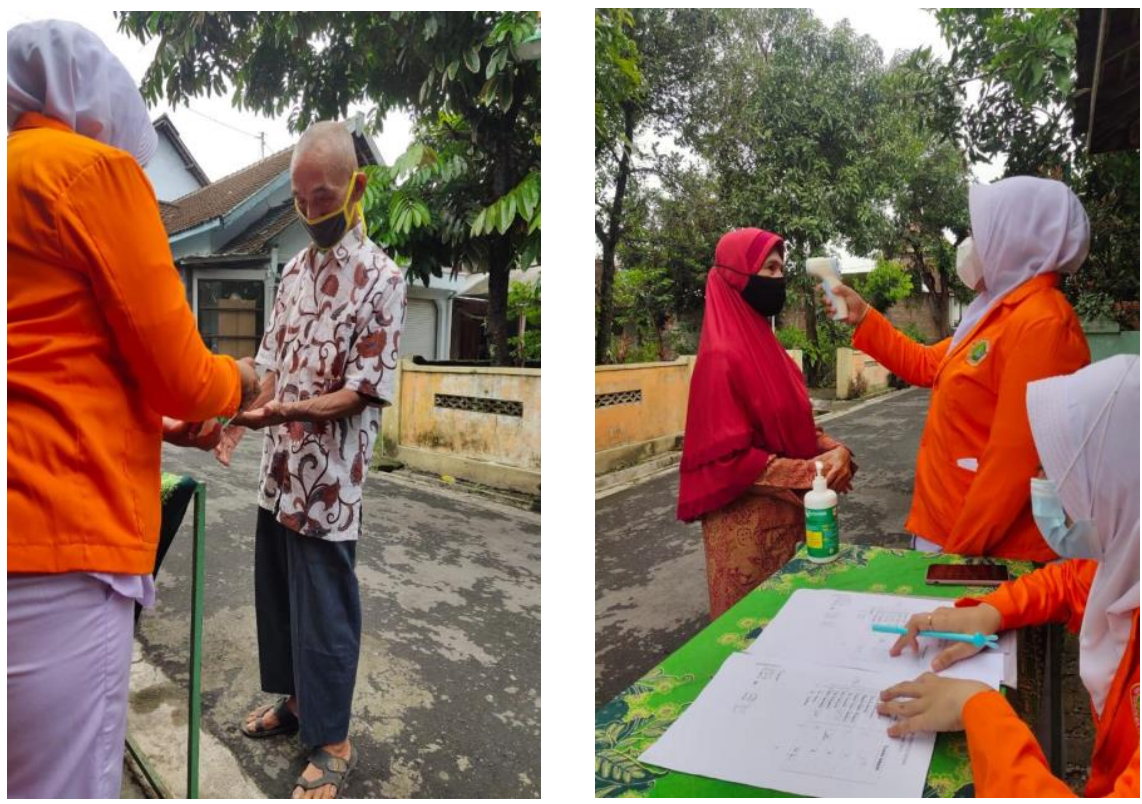

Pelaksaaan pendidikan kesehatan diawali dengan protokol kesehatan yang meliputi seluruh peserta menggunakan masker, pengukuran suhu tubuh, cuci tangan dengan hand sanitizer, dan jaga jarak. Proses penyampaian materi tentang upaya pencegahan dan pengendalian covid-19 dilaksanakan selama 30 menit.
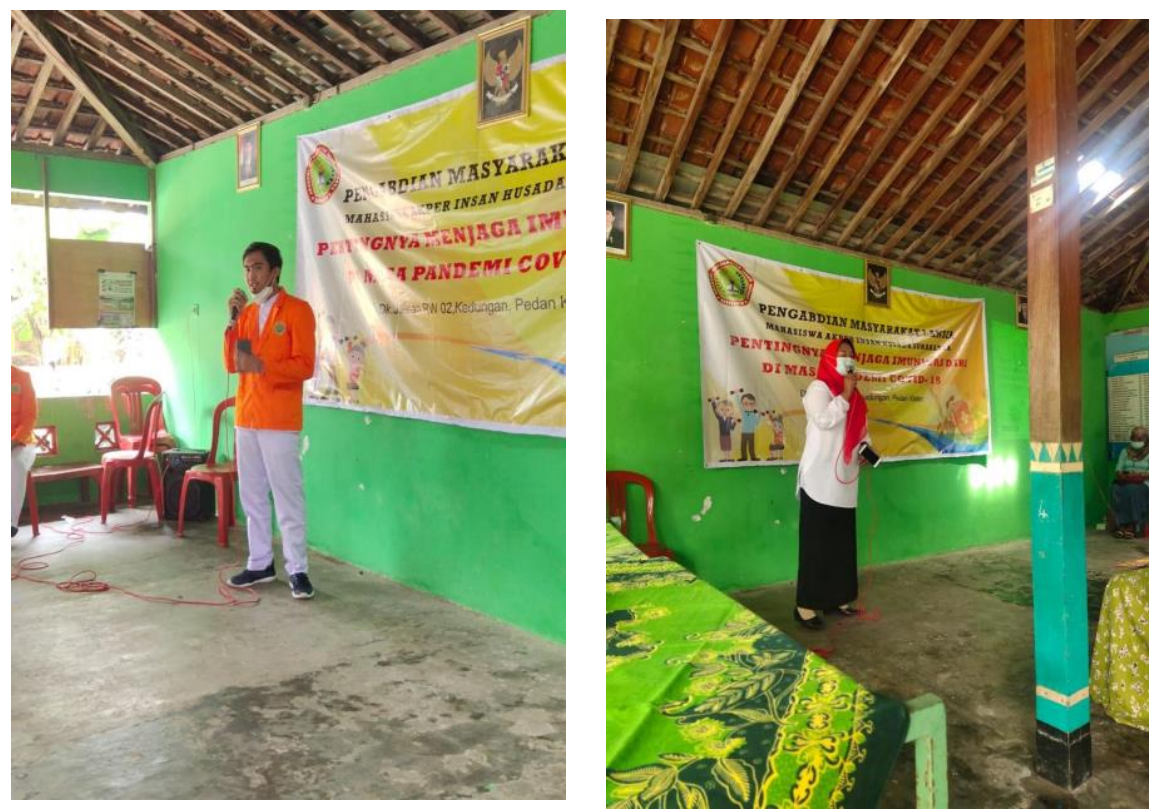

Saat penyampaian materi peserta sangat antusias dan mendengarkan narasumber dengan baik. Peserta banyak yang mengajukan pertanyaan tentang pencegahan covid-19. 


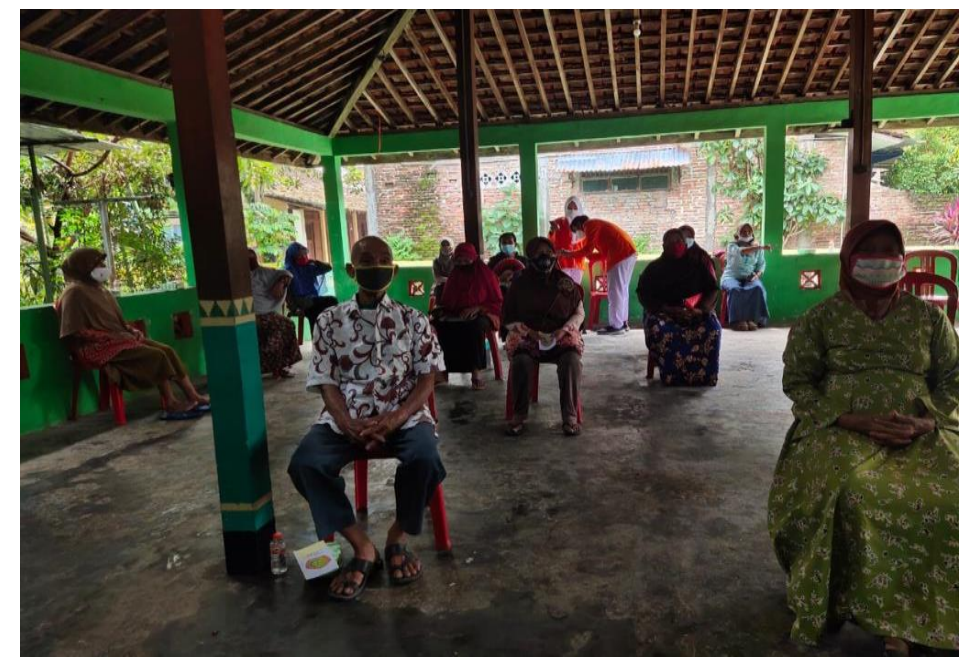

Pelaksanaan pendidikan kesehatan diakhiri dengan post test, responden diberi pertanyaan sesuai materi yang disampaikan. Responden menjawab dengan benar sesuai dengan pertanyaan yang diberikan. pendidikan kesehatan tentang pencegahan dan pengendalian covid 19 perlu diberikan kepada lansia. Hasil dari pelaksanaan pengabdian masyarakat ini adalah lansia dapat memahami cara penggunaan masker yang benar, melakukan cuci tangan benar dan harapannya bisa terhindar dari virus covid 19.

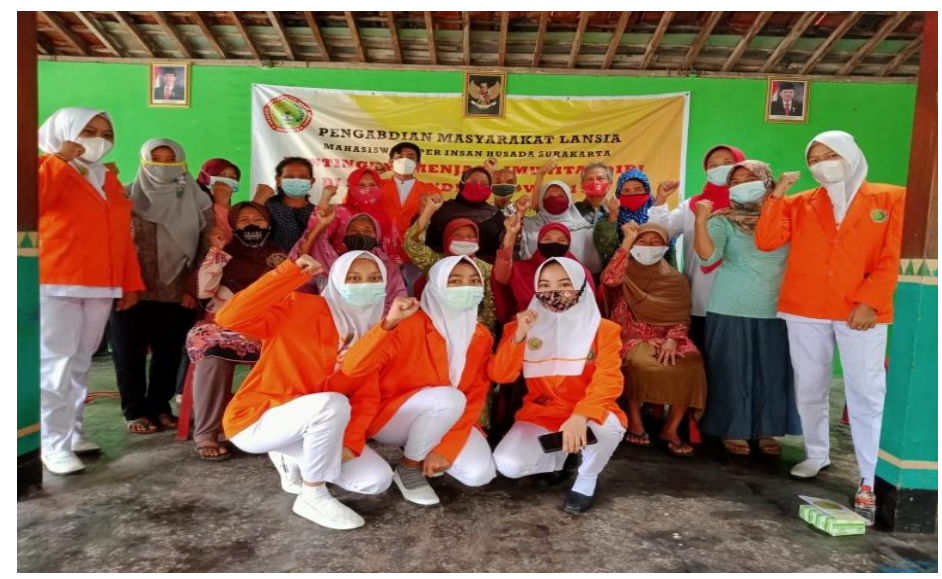

Pemberian pengatahuan tentang covid 19 merupakan program jangka pendek yang direncanakan pemerintah dalam rangka meningkatkan pengetahuan dan pemahaman akan ancaman kesehatan, ekonomi dan keamanana dari pandemic covid 19 dengan strategi komunikasi terfokus menyasar kelompok lansia (Hakim, 2021). Pencegahan covid 19 dengan penerapan protocol kesehatan salah satunya dengan penggunaan masker medis yang dilalapisi masker kain bagi masyarakat yang beraktifitas di luar rumah (Rahmi.dkk, 2021).

Imunitas ibarat system pertahanan tubuh yang terdiri tas sel, jaringan dan organ yang kompleks. Umur semakin bertambah kemampuan imun dalam melindungi tubuh juga berkurang. Namun terdapat strategi yang bisa diterapkan oleh lansia untuk meningkatkan system kekebalan tubuh. Dengan menggabungkan gaya hidup sehat dan aktif berpotensi memperkuat system kekebalan tubuh mereka unutk mencegah dan melawan penyakit dengan lebih baik di usia lansia (Telaumbanua, 2020). 
Cara meningkatkan daya tahan tubuh lansia menurut Kemenkes (2017) yaitu dengan rajin mencuci tangan, pemberian vaksin, makan makanan yang sehat, aktif bergerak, menghindari beban pikiran dan stress, tidur yang cukup, berhenti merokok dan berjemur. Upaya selanjutnya yang bisa dilakukan untuk meningkatkan derajat kesehatan dan kesejahteraan lansia selain protocol kesehatan $5 \mathrm{M}$ adalah pemantauan kesehatan pada lansia di masa pandemi (Kusumawardani, 2021).

Pemantauan kesehatan pada lansia dapat dilakukan di posyandu. Pelayanan di posyandu bisa berupa pengukuran tekanan darah untuk mendeteksi resiko terjadinya hipertensi (Rosidin.dkk, 2021).

\section{KESIMPULAN}

Pendidikan kesehatan dilakukan di dukuh Jalinan desa Kedungan Pedan Klaten. Acara diikuti 12 peserta, terdiri dari responden terbanyak adalah usia 55 - 65 tahun sebanyak 66\%, responden terbanyak adalah perempuan sebanyak 58,3\%, tingkat pendidikan menengah sebanyak 50\%. Lansia dapat memahami cara penggunaan masker yang benar, melakukan cuci tangan benar

\section{DAFTAR PUSTAKA}

Dinkes klaten. (2021). Sukseskan vaksinasi covid-19 bagi lansia. http://dinkes.klatenkab.go.id/promkes/2021/03/17/sukseskanvaksinas-covid-19-bagi-lansia/

Hakim, Luqman Nul. (2021). Pelindungan Lanjut Usia Pada Masa Pandemi Covid-19. https://berkas.dpr.go.id/sipinter/files/sipinter-1010-92420200713150239.pdf

Isfandiari, M.A. (2020). Corona Virus (Covid-19) Hasil Kajian. Dosen FKM Unair

Kementrian Kesehatan Republik Indonesia. (2017). Pedoman Kesiapsiagaan Menghadapi MERSCoV di Indonesia

Kementrian Kesehatan Republik Indonesia. (2017). Peraturan mentri kesehatan Republik Indonesia Nomor 27 Tahun 2017 Tentang Pdoman PPI. Pencegahan dan Pengendalian Infeksi (PPI)

Kusumawardani, P.A. (2021). Peningkatan Peran Kader Lansia dalam Meningkatkan Kesehatan Lansia di masa pandemi covid-19 Desa Penatarsewu Kecamatan Tanggulangin Sidoarjo.

Suryani, Y. (n.d.). Implementasi Gaya Hidup Kerohanian Mahasiswa Toraja Dalam Menyikapi Pencegahan Covid-19.

Telaumbanua, D. (2020). Urgensi Pembentukan Aturan Terkait Pencegahan Covid-19 di Indonesia. QALAMUNA: Jurnal Pendidikan, Sosial, Dan Agama, 12(01), 59-70

World Health Organization. (2020). https://www.who.int/healthtopics/coronavirus\#tab=tab_1

Rahmi. (2021). Perlindungan Masyarakat PIDIE Dari Covid 19 Melalui Pemakaian Masker. Jurnal Keperawatan Pengabdian Kepada Masyarakat volume 4 Nomor 4.

Rosidin. (2021). Upaya Peningkatan Pelayanan Posyandu Citra Saat Pandemi Covid 19 RW 12 Desa Jayaraga Garut. Jurnal Keperawatan Pengabdian Kepada Masyarakat volume 4 Nomor 4. 